\title{
On the internationalization of CAD learning through an English glossary
}

\author{
Raquel Plumed ${ }^{10000-0001-8018-8039]}$; Victoria Pérez-Belis 1[0000-0002-7545-917X]; Anna Agustín- \\ Claramonte $^{2}$; Néstor Jarque-Bou ${ }^{10000-0001-7793-3309]}$; Carmen González-Lluch ${ }^{10000-0002-9839-}$ \\ ${ }^{5615]}$ and Ana Piquer ${ }^{10000-0003-1601-0310]}$ \\ ${ }^{1}$ Dpt. Mechanical Engineering and Construction, Universitat Jaume I, Av. Sos Baynat s/n, \\ 12071 Castellon, Spain \\ ${ }^{2}$ IES Matilde Salvador, Av. de Casalduch 120, 12005 Castellon, Spain \\ plumedeuji.es
}

\begin{abstract}
The internationalization of higher education is an essential factor to improve the quality and efficiency of Spanish universities, providing students with the main skills, and knowledge to interact effectively in an international and multicultural work context as professionals. The internationalization of universities must be a transversal process, not exclusive of its territorial dimension, aimed at advancing towards a society and a knowledge economy that propitiate a solid and stable model of development and growth. To this end, professors in the area of Graphic Expression for Engineering at the Universitat Jaume I (UJI) have developed an online glossary of specific terms in English related to the 3D modelling CAD tools used in Graphic Engineering subjects. This new online tool seeks to train students to increase their technical vocabulary in English and improve their learning and communication skills to face possible collaborations in future European projects. The glossary is introduced weekly to the students during the course. Subsequently, a survey is conducted to the students to verify the effectiveness of the training. This work collects the results and conclusions of this analysis.
\end{abstract}

Keywords: Online glossary, 3D modelling, Engineering graphics.

\section{Introduction}

Nowadays employers prefer to take employees who have soft skills or a professional training in transversal competencies. The word soft skill is a sociological term referring EQ-the Emotional intelligence quotient of a person [1, 2]. Soft skills are the abilities that help to become a complete professional. On the other hand, hard skills are the technical skills achieved by the students mainly in the traditional academic courses. During the last years, university programs have increased in emphasis on soft skills and particularly communication skills.

Globalization demands a more competitive workforce and opens the labor market to a broader area than a local region. Besides, globalization forces companies to work in 
an international environment. Different languages should not be an obstacle in the globalized market. According to the number of native speakers, the three most spoken languages in the world are in order: Chinese, Spanish and English. But according to the total number of people who speak a language, whether or not the language is their mother tongue, the ranking changes. The order in this case is: English, Chinese and Hindi. Spanish is in the fourth place according to Ethnologue's study [3]. UJI university is located in Castellon (Spain), then Spanish is a mother tongue for most of the students. Nevertheless, demands of English skills by potential employers and professional bodies reflect the great importance of including English language communication skills in the university curricula.

Internationalization is also part of the university aims. Students can take a semester or a course in other university all around the world with a similar technical curriculum to the original grade at their own one.

The authors are lecturers and professors in the area of Graphic Expression for Engineering at the UJI university. The present work is focused on the subject "Technical Graphics Communication". This subject is taught in the second semester of the first course in Engineering: Industrial Engineering, Chemical Engineering, Electrical Engineering and Mechanical Engineering. With the aim of introducing students to English language communication skills, and considering that virtual learning allows the interactivity and promotes the motivation, efficiency and the improvement of the knowledge in a flexible environment [4], they have prepared an English glossary including terms related with the subject.

This paper is structured in the next sections: section 2 describes the methodology employed to design and create the educational website and the study conducted on the usability of the website by the users, section 3 presents the analysis of the results and section 4 sums up the main conclusions obtained.

\section{Methodology}

Three main stages were followed in order to complete the experience: the selection and definition of main terms, the design and use of the educational website and finally, the definition of a survey for students to evaluate the glossary and the usability of the educational website.

\subsection{Selection and definition of specific terms of 3D modelling CAD tools}

After a review of different material related to 3D modelling, such as books [5, 6], website pages [7], and support provided by different CAD software's [8], a list of 40 terms was defined. These were divided between two main groups: those related to the sketch stage (previous step required to define the geometry of the figure) and some others related to modelling (providing a solid feature from a previous sketch). The list of several terms was reviewed by teachers, who were responsible for the selection of the 21 final terms. Table 1 shows the terms selected and defined to be used by students. 
Table 1. Terms selected by teachers.

\begin{tabular}{ll|ll}
\hline Content & Term & Content & Term \\
\hline Sketch terms & Main plains & Model terms & Extrusion \\
& Origin & Revolution \\
Circle & & Loft \\
& Line & Swept \\
Arc & Fillet \\
Polygon & Feature tree \\
Spline & \\
Axis & \\
Fix constraint & \\
Dimensional constraints & \\
Geometrical constraints & \\
Over-constrained sketch & \\
Fully constrained sketch & \\
Under-constrained sketch & \\
\hline
\end{tabular}

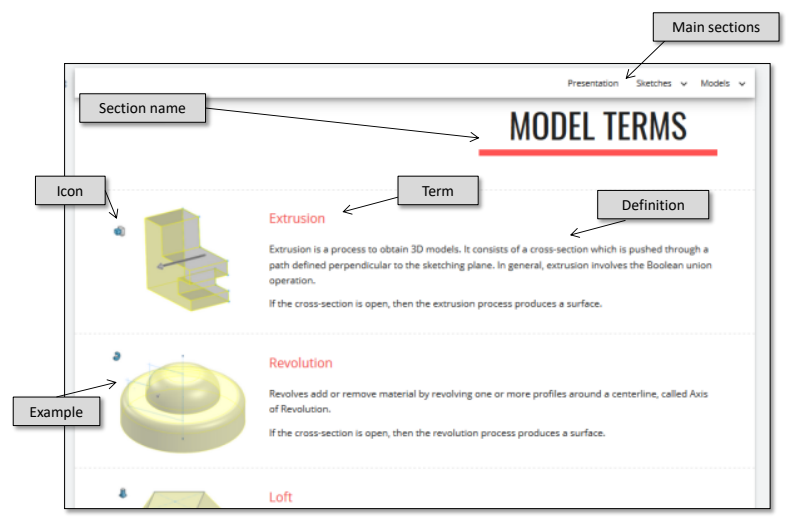

Fig. 1. Website caption.

\subsection{Design and use of the educational website}

Once the terms were selected, an educational website page was developed in order to host the glossary for students [9]. The website was developed and designed using Google Sites, as it takes advantage of working in the cloud (allowing collaboration of all teachers) and no hosting fees.

The aim of the website design was to provide an easy and intuitive tool for students to be used. Figure 1 shows and example of the design of the website. 


\subsection{Definition of a survey for students}

After students were using the website during some sessions, a survey to evaluate their usefulness was developed in order to know their opinion about that.

The survey consists of three main blocks. The first one helps to characterize the basic traits of the people who take part in the study (gender, bachelor degree, and level of English).

The second block extracts information on the general opinion that the proposed resource deserves the participants. Some of the questions formulated in this block are open-ended to receive comments and ideas for improvement proposed by the participants.

The third block is related to a usability study. To obtain a consistent result we have applied a standard analysis known as System Usability Scale (SUS). The SUS was invented by John Brooke in $1996[10,11]$ and has proven to be a reliable method to evaluate the usability of the systems compared to industry standards. It consists of a 10item questionnaire with a Likert scale. Participants rank each question from "strongly agree" to "strongly disagree". These responses are subsequently translated into a numerical score. Applying the SUS calculation method, a usability score is obtained in the range of $0-100$. The results do not represent a percentage, but a score to measure the level of usability when users interact with the website. The average score of the SUS is 68 . With a score of 80.3 or higher, users express their full satisfaction with the use of the website. If the score is less than 51 , the website must be redesigned to improve user satisfaction. Questions of the survey are shown in Table 2.

Table 2. Questions of the students' survey.

\begin{tabular}{|c|c|c|}
\hline Aim & Question & Possible answer \\
\hline \multirow{14}{*}{$\begin{array}{l}\text { To know the profile } \\
\text { of students }\end{array}$} & \multirow{4}{*}{$\begin{array}{l}\text { Please, indicate your bachelor de- } \\
\text { gree }\end{array}$} & Industrial Engineering \\
\hline & & Chemical Engineering \\
\hline & & Electrical Engineering \\
\hline & & Mechanical Engineering \\
\hline & \multirow[t]{3}{*}{ Gender } & Male \\
\hline & & Female \\
\hline & & Other \\
\hline & \multirow[t]{7}{*}{ English level } & Lower Intermediate B1 (PET) \\
\hline & & Intermediate B2 (FIRST) \\
\hline & & Upper Intermediate $\mathrm{C} 1$ \\
\hline & & (ADVANCED) \\
\hline & & Advanced C2 (PROFICIENCY) \\
\hline & & Pre-intermediate A2 \\
\hline & & Without English studies \\
\hline $\begin{array}{l}\text { To know the need } \\
\text { of the glossary }\end{array}$ & $\begin{array}{l}\text { Do you think it is necessary to in- } \\
\text { troduce English in this type of } \\
\text { subjects? Why? }\end{array}$ & Open answer \\
\hline
\end{tabular}




\begin{tabular}{|c|c|c|}
\hline & $\begin{array}{l}\text { Do you consider that its domain } \\
\text { in this area is necessary for your } \\
\text { professional future? Why? }\end{array}$ & Open answer \\
\hline \multirow{5}{*}{$\begin{array}{l}\text { To know the use- } \\
\text { fulness of the glos- } \\
\text { sary }\end{array}$} & $\begin{array}{l}\text { Have you found the terms shown } \\
\text { on the website useful? }\end{array}$ & Yes/No/Other \\
\hline & $\begin{array}{l}\text { Which terms have you found } \\
\text { most useful? }\end{array}$ & $\begin{array}{l}\text { 1. Strongly disagree/ 2. Disagree/ } 3 . \\
\text { Neither agree nor disagree/ 4. Agree/ } \\
\text { 5. Strongly Agree }\end{array}$ \\
\hline & $\begin{array}{l}\text { Which other terms would you } \\
\text { add? }\end{array}$ & Open answer \\
\hline & $\begin{array}{l}\text { Which other sections do you } \\
\text { think may be helpful? }\end{array}$ & $\begin{array}{l}\text { Evaluation questionnaires } \\
\text { Games to learn the vocabulary }\end{array}$ \\
\hline & & $\begin{array}{l}\text { Spelling exercises of the basic terms } \\
\text { Tutorials in English }\end{array}$ \\
\hline \multirow[t]{10}{*}{ SUS study } & $\begin{array}{l}\text { I think I would use this website } \\
\text { frequently }\end{array}$ & $\begin{array}{l}\text { 1. Strongly disagree/ 2. Disagree/ } 3 . \\
\text { Neither agree nor disagree/ 4. Agree/ } \\
\text { 5. Strongly Agree }\end{array}$ \\
\hline & $\begin{array}{l}\text { I find this website unnecessarily } \\
\text { complex }\end{array}$ & $\begin{array}{l}\text { 1. Strongly disagree/ } 2 \text {. Disagree/ } 3 . \\
\text { Neither agree nor disagree/ } 4 \text {. Agree/ } \\
\text { 5. Strongly Agree }\end{array}$ \\
\hline & I think the website is easy to use & $\begin{array}{l}\text { 1. Strongly disagree/ } 2 \text {. Disagree/ } 3 \text {. } \\
\text { Neither agree nor disagree/ } 4 \text {. Agree/ } \\
\text { 5. Strongly Agree }\end{array}$ \\
\hline & $\begin{array}{l}\text { I think I would need help from a } \\
\text { person with technical knowledge } \\
\text { to use this website }\end{array}$ & $\begin{array}{l}\text { 1. Strongly disagree/ } 2 \text {. Disagree/ } 3 . \\
\text { Neither agree nor disagree/ } 4 \text {. Agree/ } \\
\text { 5. Strongly Agree }\end{array}$ \\
\hline & $\begin{array}{l}\text { The functions of this website are } \\
\text { well integrated }\end{array}$ & $\begin{array}{l}\text { 1. Strongly disagree/ } 2 \text {. Disagree/ } 3 . \\
\text { Neither agree nor disagree/ } 4 \text {. Agree/ } \\
\text { 5. Strongly Agree }\end{array}$ \\
\hline & $\begin{array}{l}\text { I think the website is very incon- } \\
\text { sistent }\end{array}$ & $\begin{array}{l}\text { 1. Strongly disagree/ } 2 \text {. Disagree/ } 3 . \\
\text { Neither agree nor disagree/ } 4 \text {. Agree/ } \\
\text { 5. Strongly Agree }\end{array}$ \\
\hline & $\begin{array}{l}\text { I imagine that most people would } \\
\text { learn to use this website very } \\
\text { quickly }\end{array}$ & $\begin{array}{l}\text { 1. Strongly disagree/ } 2 \text {. Disagree/ } 3 . \\
\text { Neither agree nor disagree/ } 4 \text {. Agree/ } \\
\text { 5. Strongly Agree }\end{array}$ \\
\hline & $\begin{array}{l}\text { I find that the website is very dif- } \\
\text { ficult to use }\end{array}$ & $\begin{array}{l}\text { 1. Strongly disagree/ } 2 \text {. Disagree/ } 3 . \\
\text { Neither agree nor disagree/ } 4 \text {. Agree/ } \\
\text { 5. Strongly Agree }\end{array}$ \\
\hline & $\begin{array}{l}\text { I feel confident in using this web- } \\
\text { site. }\end{array}$ & $\begin{array}{l}\text { 1. Strongly disagree/ } 2 \text {. Disagree/ } 3 . \\
\text { Neither agree nor disagree/ } 4 \text {. Agree/ } \\
\text { 5. Strongly Agree }\end{array}$ \\
\hline & $\begin{array}{l}\text { You need to learn many things } \\
\text { before being able to use this web- } \\
\text { site. }\end{array}$ & $\begin{array}{l}\text { 1. Strongly disagree/ } 2 \text {. Disagree/ } 3 \text {. } \\
\text { Neither agree nor disagree/ } 4 \text {. Agree/ } \\
\text { 5. Strongly Agree }\end{array}$ \\
\hline
\end{tabular}




\section{Results}

A total of 50 students answered the online questionnaire, all of them enrolled in the first-year subject of Technical Drawing Communication. Students belonged to different Engineering degrees, specifically the sample consists of 7 students of chemical engineering, 7 of electrical engineering, 18 of industrial engineering and 19 of mechanical engineering. Of the total participants, 15 were women and 35 were men.

The participating students signed electronically a data protection agreement. This document showed the questionnaire's purpose and explained that teachers assure confidentiality and protect the personal data handled.

As Figure 2 shows, more than half of the participants has an intermediate level of English (level B1 or B2).

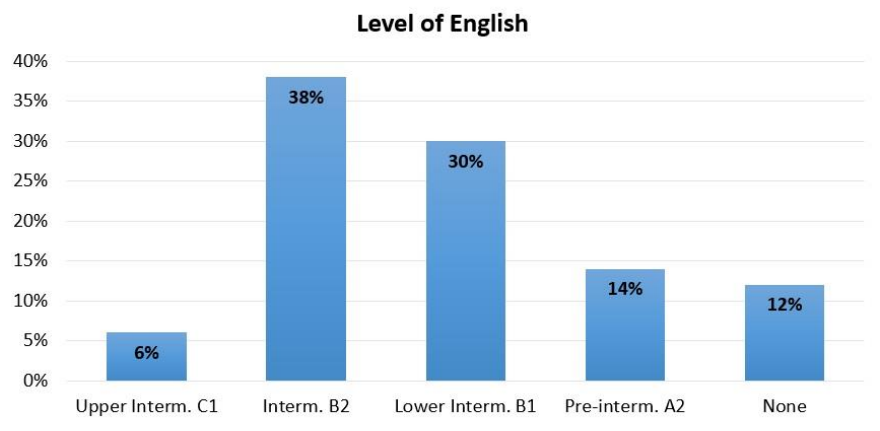

Fig. 2. Level of English of the participants.

Table 3. Questions and relative frequencies in answers of the second block.

\begin{tabular}{llc}
\hline Questions & Answers & Rel. Freq. \\
\hline $\begin{array}{l}\text { Do you think it is necessary to } \\
\text { introduce English in this type }\end{array}$ & Yes, to have a better professional future. & $40 \%$ \\
of subjects? Why? & Yes, because English is important. & $34 \%$ \\
& Yes, because many software works in English & $10 \%$ \\
& No, it is not necessary & $10 \%$ \\
& No, that would only complicate the subject. & $6 \%$ \\
\hline Do you consider that its do- & Yes, to work in international companies. & $8 \%$ \\
main in this area is necessary & Yes, to work abroad. & $14 \%$ \\
for your professional future? & Yes, to have a better professional future. & $34 \%$ \\
Why? & Yes, because English is important. & $29 \%$ \\
& Not much in this area. & $6 \%$ \\
& DK/NA & $10 \%$ \\
\hline Which other terms would you & I would not add anything else. & $26 \%$ \\
& More modelling terms. & $18 \%$ \\
& More detailed explanations. & $8 \%$ \\
& Tutorials from the teachers. & $8 \%$ \\
& More exercises/examples. & $6 \%$ \\
& DK/NA. & $34 \%$ \\
\hline
\end{tabular}


Table 3 presents a summary of the open questions (first column) and the answers obtained (second column). Answers are described by their relative frequency (right column).

The results show that $84 \%$ of the students agree with the idea of introducing English in the subject, the reasons are different: $40 \%$ of the participants believe that English is essential to have a better professional future; $34 \%$ consider that English is important enough in itself and $10 \%$ believe that it is the main language used in technical software. The second question reaffirm the idea that students are concerned about their professional future since their first year at university-it is the most frequent response in the first two questions - and it is also remarkable that $14 \%$ of the students already consider the option of working abroad.

In the last question, the influence of social networks and new technologies is evident when up to $8 \%$ of the participants propose the addition of tutorials from the teachers.

In general, the participants consider that the terms defined in the website glossary are useful-reflected by $88 \%$ of the polled people (Figure 3 left) - and there are not many differences in the preference between the terms referred to sketches or models according to Figure 3 right: $74 \%$ of the participants consider the terms related to sketches useful or very useful and $78 \%$ for the terms referred to the models.

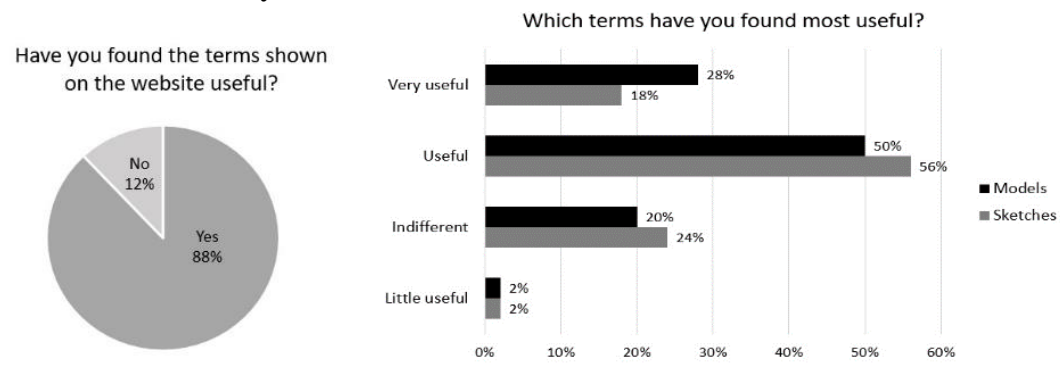

Fig. 3. Equation formatting.

Finally, after collecting the scores given by the participants in the SUS analysis to measure the usability of the website, the correspondent calculation is applied. The average score obtained is 68.5. This means that users define the Glossary website as a useful resource; however, it can still be improved.

As future work, the teachers involved in the development of this tool will have to continue working to make it more usable. A first step should be to analyse the ideas and proposals launched by the students in order to adapt the glossary to their tastes and needs.

\section{Conclusions}

The knowledge of several languages in general and of English in particular has become a challenge and a necessity for students of engineering degrees. 
It is important that students do a gradual immersion in English from the first year of their studies. For this purpose, a website glossary of terms in English related to the subject of Technical Graphic Communication has been developed.

The paper also describes the subsequent questionnaire addressed to engineering students to know their opinion and evaluate the usability of the tool.

Results show that students are aware of the importance of a knowledge of English, both personally and professionally.

The SUS test reveals that students value the usability of the developed website resource in a positive way. At the same time, students have launched some ideas and proposals to improve the glossary website. Then, the glossary website has turned out to be an effective resource to work on immersing students in English. It also represents an element of continuous improvement in teaching.

\section{Acknowledgments}

The research work reported here was made possible by the Innovative Education Project: "Aprofundiment en conceptes de modelatge 3D parametric" USE - UJI.

\section{References}

1. Choudary, V.: The importance of training engineering students in soft-skills. International Monthly Refereed Journal of Research In Management \& Technology, Vol. III, 61-64 (2014).

2. Schulz, B.: The importance of soft skills: Education beyond academic knowledge. Journal of Language and Communication, 146-154 (2008).

3. "Summary by language size". Ethnologue. [https://www.ethnologue.com/], last accessed 2019/04/03.

4. López de la Madrid, M.: Uso de las TIC en la educación superior de México. Un estudio de caso. Apertura, 7, 63-81 (2007).

5. Bertoline, G.R., Wiebe, E.N., Hartman, N., Ross, W.: Fundamentals of Graphics Communication. McGraw-Hill, 2010.

6. Lieu, D.K., Sorby, S.: Visualization, Modeling and Graphics for Engineering Design. Delmar, Cengage Learning, 2009

7. Technical Graphics Communication Glossary, http://highered.mheducation.com/sites/0073655988/student_view0/glossary27/index.html, last accessed 2019/03/30

8. SolidWorks Web Site, http://help.solidworks.com/2018/English/SolidWorks/sldworks/c_solidworks_web_site.htm, last accessed 2019/03/30.

9. CAD 3D English Glossary, https://sites.google.com/uji.es/cad-3d-english-glossary/presentation, last accessed 2019/04/01.

10. Brooke, J.: SUS: A "quick and dirty" usability scale. In: Jordan, W., Thomas, B., Weerdmeester, B. A., McClelland, A. L. (eds.), Usability Evaluation in Industry. London: Taylor and Francis (1996).

11. Brooke, J.: SUS: A retrospective. J. Usability Studies 8(2), 29-40 (2013). 